\title{
Treatment and Utilization of Municipal Solid Waste as Manure for Agriculture through Formulated Microbial Consortium Along with Bio Fertilizer Microorganisms
}

\author{
Pradeepkumar K. V*, Arunadevi P. S., Myvizhi. P \\ Department of Zoology, Sri Vasavi College, Erode, Tamil Nadu, India
}

Received April 3, 2020; Revised May 20, 2020; Accepted June 4, 2020

\section{Cite This Paper in the following Citation Styles}

(a): [1] Pradeepkumar K. V, Arunadevi P. S., Myvizhi. P , "Treatment and Utilization of Municipal Solid Waste as Manure for Agriculture through Formulated Microbial Consortium Along with Bio Fertilizer Microorganisms," Advances in Zoology and Botany, Vol. 8, No. 5, pp. 408 - 421, 2020. DOI: 10.13189/azb.2020.080505.

(b): Pradeepkumar K. V, Arunadevi P. S., Myvizhi. P (2020). Treatment and Utilization of Municipal Solid Waste as Manure for Agriculture through Formulated Microbial Consortium Along with Bio Fertilizer Microorganisms. Advances in Zoology and Botany, 8(5), 408 - 421. DOI: 10.13189/azb.2020.080505.

Copyright $\bigcirc 2020$ by authors, all rights reserved. Authors agree that this article remains permanently open access under the terms of the Creative Commons Attribution License 4.0 International License

\begin{abstract}
This study focuses on application of formulated microbial consortium for the treatment of domestic solid wastes and makes it as manure for agriculture. In that context treatment by Formulated Microbial Consortium, along with Bio Fertilizer Microorganisms has been tried for treatment of municipality solid waste. Basically, this technology is using natively available microorganisms. The cultured microbial solution was used for treatment of municipal solid wastes. In the first heap, there was no treatment had been done which was called control. The second heap was treated with formulated microbial consortium containing nine microbes which were focused on decomposition and treatment of municipal solid waste. The third heap was treated with Formulated Microbial Consortium along with Bio Fertilizer Microorganism which was mainly focused on enrichment of nutrients. After treatment parameter has been analysed to evaluate the performance of the microbial consortium. After the investigation, the nutrients level was increased in the third heap and the composting time considerably decreased which increased the hope to treat municipal solid wastes effectively. The results showed significant $(\mathrm{p}<0.05)$ differences in the amount of available and total NPK levels.
\end{abstract}

Keywords Bio Fertilizer Microorganism, Formulated Microbial Consortium, Municipal Solid Wastes

\section{Introduction}

A major problem facing municipalities throughout the world is the treatment, disposal and recycling of solid wastes. According to the Ministry of Rural Development [1] in rural areas of India, domestic solid waste is a severe threat to public health and cleanliness and is having predominantly organic and biodegradable yet becoming a major problem to the overall sustainability of the ecological balance. Rural people in India are generating solid waste around 0.3 to 0.4 million metric tons per day. However, municipal wastes exhibit wide variations in the physical, chemical and biological properties [2]. The composition of solid waste is approximately around $40-60 \%$ compostable wastes like food and garden wastes, 30-50\% inert wastes like glass, metal, inert materials, plastic, rubber products, and waste cloths, around 10-30\% recyclable wastes [3]. Generally municipal waste consists mainly of biodegradable organic materials with a significant amount of inorganic matter [4]. When these wastes are dumped frequently on road sides of the cities and villages, they do not decompose very quickly because various types of materials having their capacity for degradation.

Lack of municipal solid waste management (MSWM) and disposal is leading to significant environmental problems. Municipalities not able to segregate the solid wastes and dumping them along the road and peripheral water body sides due to many reasons can cause severe sanitation 
problems includes soil, air water, and aesthetic pollution, such environmental problems are associated with human health disorder. Solid waste management (SWM) involves activities associated with generation, storage and collection, transfer and transport, treatment and disposal of inert material in solid wastes. But, in most Indian cities, the MSWM system comprises only four activities, i.e., waste generation, collection, transportation, and disposal. Poor collection and inadequate transportation cause the accumulation of MSW at every nook and corner [5].

Absence of proper disposal of solid waste, they are leading to vector born diseases such as Diarrhoea, Malaria, Polio, Dengue, Typhoid and other water borne infections such as Schistosomiasis, Cholera etc., Close to $88 \%$ of the total disease load is due to lack of clean water \& sanitation and improper solid and liquid waste management [1]. Adverse impact on all components of the environment and human health occurs due to unscientific disposal of MSW [6].

There are a number of treatment technologies are available to treat the MSW but every method has its own limitations. Hence innovative and simple technologies are required to treat the MSW in sustainable manner for all types of dumping yard. It has been recognized quite recently that biological systems, primarily of usage of microbes could prove potential means of degrading some such complex environmental pollutants as well as preventing pollution through waste treatment. Application of microbes for MSW treatment is one of the innovative technologies. Application of formulated microbial consortium based on waste which is used to treat the domestic solid wastes in all environmental condition.

Living microorganisms has been used to prepare Bio Fertilizer Microbes (BFM) based on their metabolic activities which were responsible to supply of nutrients, influence the growth and physiology of the plants [7]. Reason for the biofertilizer promotion was to avoid environmental hazard and sustainable growth of agriculture [8]. For the agricultural eco system microbes play vital role in nutrients fixing, solubilizing, mobilizing and recycling. There were plenty of microbes which was existing naturally but the population was minimal to enhance specific population of chosen microbes has been artificially cultured and mixed-up with growth media which was suitable for proliferation of microbial load. In our present investigation there were nine microbes were used in Formulated Microbial Consortium (FMC) for the treatment and decomposition of solid waste and four microbes in BFM were used to influence to increase the available major nutrients such as NPK in the manure. The objectives of the investigation were to evaluate the performance of formulated microbial consortium along with Bio fertilizer microorganism $(\mathrm{FMC}+\mathrm{BFM})$ on domestic solid wastes.

\section{Materials and Methods}

\subsection{Study Area}

The present investigation was carried out in the Konamoolai village Panchayat (Latitude: $11^{0} 29^{\prime} .0^{\prime} \mathrm{N}$; Longitude: $\left.77^{0} 14^{\prime} 00.7^{\prime \prime} \mathrm{E}\right)$ of Sathyamangalam Taluk, Erode District, Tamil Nadu, India. The Municipal Solid waste has been segregated and makes it as three different heaps. Each one has $500 \mathrm{~kg}$ capacity of domestic biodegradable solid waste. First heap is called Municipal Solid Waste - I control it will be treated with de-chlorinated water only to maintain the proper moisture level (30-35\%). In the second one Municipal Solid WasteII (MSW-II), first week alone sprays the FMC then weekly once spray the water to maintain the moisture, in the third heap was Municipal Solid Waste - III (MSW-III), first week sprayed FMC after fifteen days BFM has been sprayed and the rest of the week's water was sprayed to maintain the proper moisture level. After 42 days to 84 days weekly once test sample have been taken from all heaps and send it to physico-chemical parameter analysis.

\subsection{Description of Formulated Microbial Consortium (FMC)}

Basically, the FMC+BFM Technology are using microbial culture with the locally available microorganisms. The FMC contains different strains of bacterial species. These microorganisms were purchased from Microbial Type Culture Collection Center (MTCC), Chandigarh, India and grown in specific media as per MTCC recommendation. They are: Lactobacillus fermentum (MTCC-903), Lactobacillus bifermentans (MTCC-3818), Rhodopseudomonas sp., (MTCC- 8756), Cellulomonas fimi (MTCC-24), Psudomonas fluorescens (MTCC-664) and the fungal species are Saccharomyces cerevisiae (MTCC- 212), Beauveria bassiana (MTCC-4492), Phanerochaete chrysoporium (MTCC787) and Mucor hiemalis (MTCC-157).

From the specific media the microbes were taken and cultured in media which has common nutrients for all microbes. The cultured microbial solution was used for treatment. The reason for choosing this FMC was naturally occurring non toxic mixture of beneficial microbes having the ability to quickly consume and digest a variety of organic matter, which is not harmful to human or to the nature (non pathogenic), reproduces quickly in the conditions present in waste disposal systems and efficiently removes foul odor, wide range of $\mathrm{pH}$ and temperature tolerance, co-existing nature and facultative anaerobic which will survive in both aerobic and anaerobic condition. 


\subsection{Description of Bio Fertilizer Microorganisms (BFM)}

The biofertilizer microorganisms contain four different type of microbes which are commercially available, commonly used to solubilize the nitrogen, phosphorus and potash in the given substrates. They are Azospirillum orizae (MTCC- 9757), Rhizobium leguminosarum (MTCC-99), Bacillus megaterium (MTCC- 2444) and Potash solubilizing bacteria Frateuria aurantia (Purchased from OMEGA Ecotech, Coimbatore, TN, India).

\subsection{Preparation of Microbial Solution for Field Applications}

The FMC and FMC + BFM were prepared in the form of

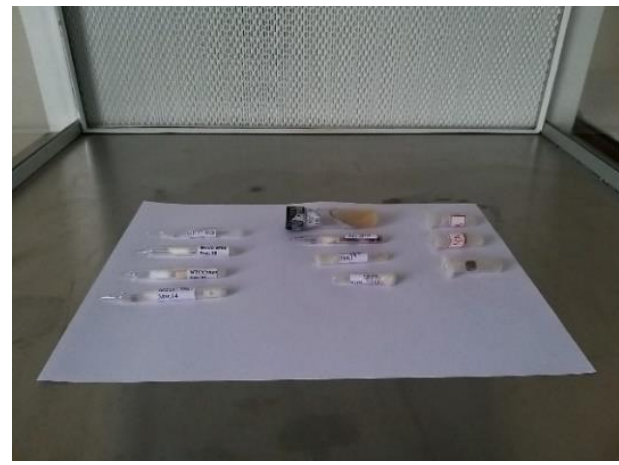

Seed Culture from MTCC

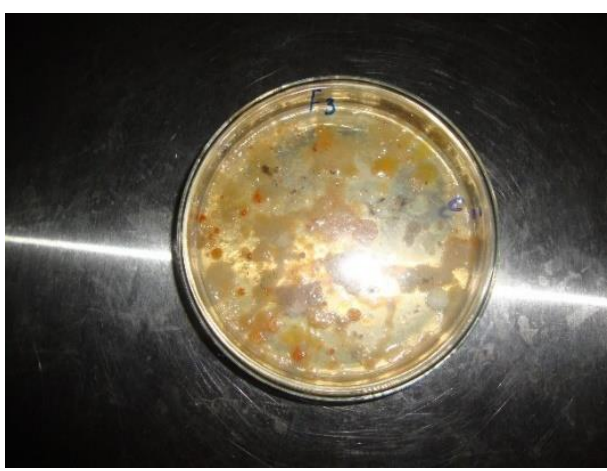

Co existing Activity of Different Microbes

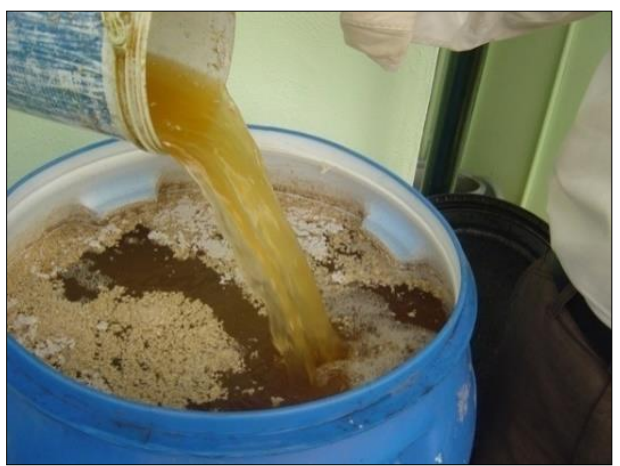

Application Culture a mother culture. The cell counts in the mother culture were around $10^{9} \mathrm{CFU}$. Then it was mixed equal quantity and makes it as mother culture. The mother culture was extended or activated. Previously the barrel was washed with chlorine free water and dried in sunlight for application solution production. Cleaned barrel was filled with $1 \mathrm{~L}$ mother culture was mixed with $50 \mathrm{~L}$ of chlorine free water (1:50) and $800 \mathrm{gm}$ of cane sugar (Jaggery) in a pre-formulated ratio. The mixture was kept for 7 days under anaerobic conditions and is called application culture. The nature of application cultures $\mathrm{pH}$ range is 5-6.5, Straw yellow to Dark brown in colour, slightly souring colour, Density is around 1.0. The cell count FMC and FMC + BFM were around $10^{6} \mathrm{CFU}$ (Table 1\&2). After seven days it was become the application culture.

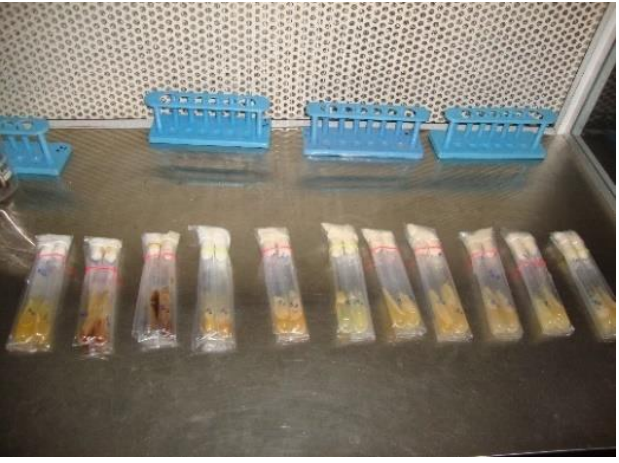

Slant Culture

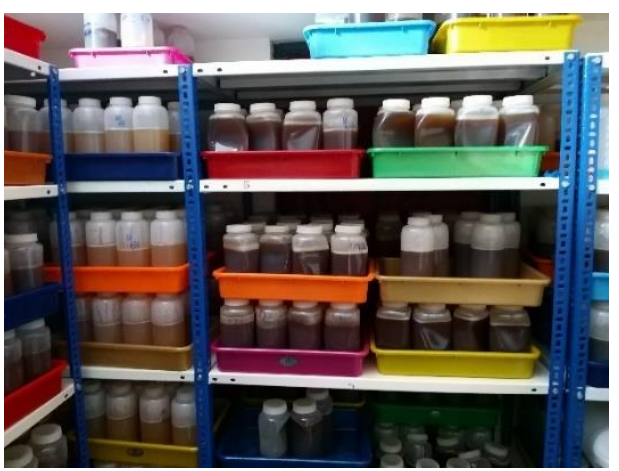

Broth Culture

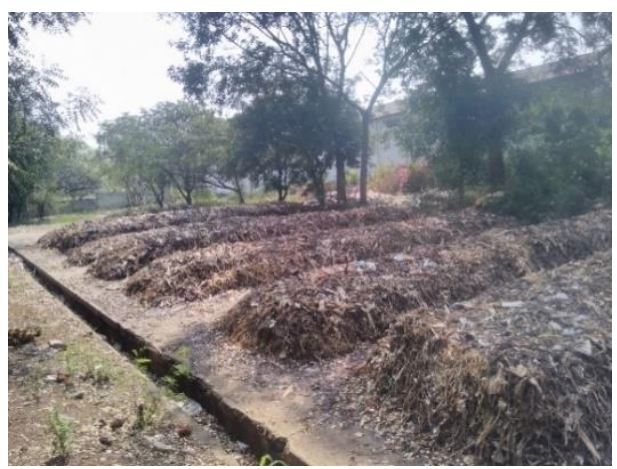

Composting Practice

Figure 1. FMC and BFM Preparation and Application 
Table 1. Microbes of Formulated Microbial Consortium Solution

\begin{tabular}{|l|l|l|}
\hline Sl. No & Microbial species & Cell Count (Cells/ml) \\
\hline \multicolumn{2}{|l|}{ Bacterial Species } & $1.3 \times 10^{9} \mathrm{Cells} / \mathrm{ml}$ \\
\hline 1 & Lactobacillus fermentum & $1.2 \times 10^{9} \mathrm{Cells} / \mathrm{ml}$ \\
\hline 2 & Lactobacillus bifermentans & $1.4 \times 10^{9} \mathrm{Cells} / \mathrm{ml}$ \\
\hline 3 & Rhodopseudomonas sp. & $1.3 \times 10^{9} \mathrm{Cells} / \mathrm{ml}$ \\
\hline 4 & Cellulomonas fimi & $1.3 \times 10^{9} \mathrm{Cells} / \mathrm{ml}$ \\
\hline 5 & Psudomonas fluorescens & \\
\hline Fungal Species & Saccharomyces cerevisiae & $1.6 \times 10^{9} \mathrm{Cells} / \mathrm{ml}$ \\
\hline 1 & Beauveria bassiana & $1.2 \times 10^{9} \mathrm{Cells} / \mathrm{ml}$ \\
\hline 2 & Phanerochaete chrysoporium & $1.3 \times 10^{9} \mathrm{Cells} / \mathrm{ml}$ \\
\hline 3 & Mucor hiemalis & $1.3 \times 10^{9} \mathrm{Cells} / \mathrm{ml}$ \\
\hline 4
\end{tabular}

Table 2. Bio Fertilizer Microorganisms

\begin{tabular}{|l|l|l|}
\hline Sl. No & Microbial species & Cell Count $($ Cells $/ \mathrm{ml})$ \\
\hline Bio Fertilizer Microorganisms \\
\hline 1 & Azospirillum orizae & $1.3 \times 10^{9}$ Cells $/ \mathrm{ml}$ \\
\hline 2 & Rhizobium leguminosarum & $1.2 \times 10^{9} \mathrm{Cells} / \mathrm{ml}$ \\
\hline 3 & Bacillus megaterium & $1.4 \times 10^{9}$ Cells $/ \mathrm{ml}$ \\
\hline 4 & Frateuria aurantia & $1.3 \times 10^{9}$ Cells $/ \mathrm{ml}$ \\
\hline
\end{tabular}

\subsection{Sampling and Analysis}

From 42 days to 84 days weekly once three samples were taken from all heaps. The first sample was stored at $4^{0} \mathrm{C}$ to provide a sample library. The second sample was keep it in shadow dry, make it as powder then sieved in 4 $\mathrm{mm}$ sieve and taken into laboratory for physico-chemical analysis. At each sampling period, the $\mathrm{pH}$ was determined using $\mathrm{pH}$ meter (1:10, water: extract), Electrical Conductivity was determined using EC meter. Both parameters were carried out following the procedures of The Standard Methods for the Examination of Water and Wastewater [9]. The chemical composition of the samples was determined, including the organic carbon [10], nitrogen [11] potassium [12] and phosphate [13] concentrations.

\subsection{Statistical Analysis}

All experiments were conducted in triplicate. The values reported in this study are mean \pm SD and one way ANOVA of variance was performed by using SPSS (version 21). The significant means were compared by Dunnett's test and a $\mathrm{p}<0.05$ was considered as statistically significant analysis.

\section{Results}

The changes of nutrients level in MSW - I control, MSW - II FMC treated and MSW - III FMC+BFM treated were present in Table 3. In this study the result shows significant difference among the composts are at 0.05 levels of significance (Table $3 \& 4$ ). The $\mathrm{pH}$ was $8.15 \pm 0.08$ for MSW - I control, 8.15 \pm 0.29 for MSW - II FMC treated and $7.34 \pm 0.25$ for MSW - III - FMC+BFM treated. The EC of MSW-I Control was $3.56 \pm 0.03 \mathrm{mS} / \mathrm{cm}$, MSW - II treated with FMC was $3.19 \pm 0.18 \mathrm{mS} / \mathrm{cm}$, MSW - III treated with $\mathrm{FMC}+\mathrm{BFM}$ was $3.59 \pm 0.22 \mathrm{mS} / \mathrm{cm}$. The composts organic carbon levels in MSW-I control, MSW II treated with FMC and the MSW - III treated with FMC+BFM were $14.37 \pm 0.75 \%, \quad 23.78 \pm 2.4 \%$ and $27.46 \pm 1.44 \%$, respectively.

The total nitrogen content of the MSW-I control was $0.91 \pm 0.04 \%$, MSW - II treated with FMC was $1.62 \pm 0.07 \%$ and MSW - III treated with FMC+BFM was $1.75 \pm 0.07 \%$. The Total phosphorus content of the MSW - I Control was $0.54 \pm 0.02 \%$, MSW - II treated with FMC was $0.63 \pm 0.02 \%$ and MSW - III treated with FMC+BFM was $0.66 \pm 0.04 \%$. The potassium of the MSW - I control, MSW - II treated with FMC and MSW -III treated with FMC+BFM were $0.37 \pm 0.02 \%, 0.93 \pm 0.04 \%$ and $1.22 \pm 0.07 \%$, respectively. The available nitrogen content of the MSW - I control was $0.15 \pm 0.00 \%$, MSW - II treated with FMC was $0.25 \pm 0.01 \%$ and MSW - III treated with FMC+BFM was $0.27 \pm 0.02 \%$. The available phosphorus content of the MSW - I control was $0.01 \pm 0.00 \%$, MSW - II treated with FMC was $0.03 \pm 0.01 \%$ and MSW - III treated with FMC+BFM was $0.03 \pm 0.01 \%$. The available potassium level was increased in all composts with the increasing composting period. High rate of increasing was observed in MSW-III treated with FMC+BFM $0.56 \pm 0.03 \%$. In MSW-II treated with FMC potassium content was $0.27 \pm 0.01 \%$ and the rate at the MSW - I control was $0.11 \pm 0.01 \%$. The C:N ratio in MSW - I control was $15.74 \pm 0.3$, MSW-II treated with FMC was $15.27 \pm 1.17$ and MSW-III treated with FMC+BFM was $15.73 \pm 0.45$.

The obtained F-ratio value of parameters shown in Table. 3 was higher than the table values with df 2 and 9 required for significance at 0.05 level except C:N ratio. Since the value of F-ratio is higher than the table value, it indicates that there was significant difference among the groups of MSW II-FMC Treated, MSW III-FMC+BFM Treated and MSW - I control group.

In Dunnett's test (Table.4) showing that there was significant difference between the MSW II - FMC treated and MSW III - FMC+BFM treated groups and MSW - I control group of $\mathrm{pH}, \mathrm{EC}(\mathrm{mS} / \mathrm{cm}), \mathrm{OC}(\%)$, total $\mathrm{N}(\%)$, total $\mathrm{P}(\%)$, total $\mathrm{K}(\%)$, available $\mathrm{N}(\%)$, available $\mathrm{P}(\%)$ and available $\mathrm{K}(\%)$. The $\mathrm{pH}$ of MSW II - FMC treated and C:N Ratio of MSW - II FMC treated, MSW - III FMC+BFM treated groups with control group are insignificant. 
Table 3. Descriptive and ANOVA results of physico-chemical and nutrients level in MSW - I Control, MSW - II FMC treated and MSW - III FMC+ BFM treated

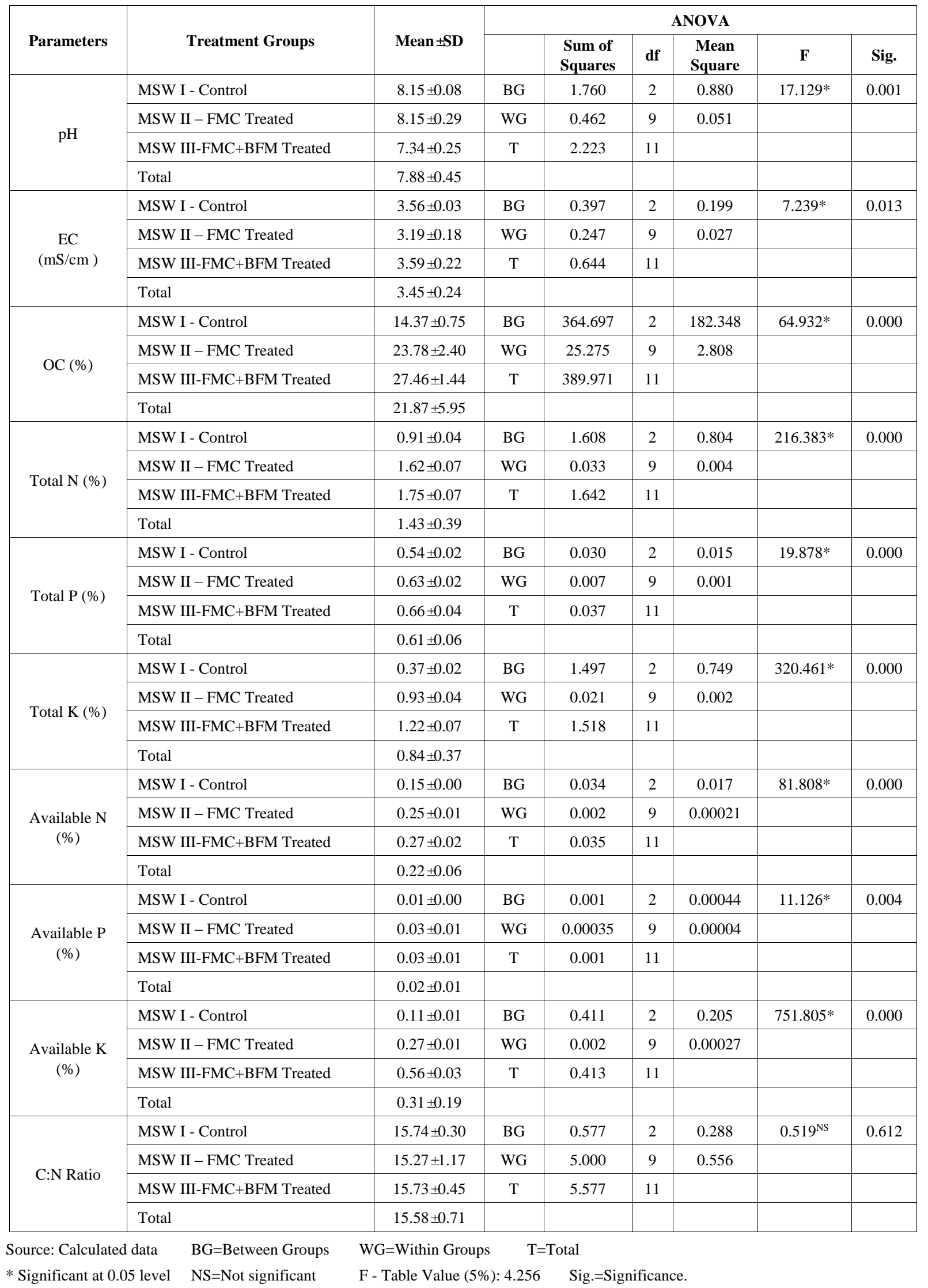


Table 4. Multiple Comparisons through Dunnett's Test ${ }^{\mathrm{a}}$

\begin{tabular}{|c|c|c|c|c|c|c|c|}
\hline \multirow{2}{*}{$\begin{array}{c}\text { Dependent } \\
\text { Variable }\end{array}$} & \multirow{2}{*}{ Treatment Groups (I) } & \multirow{2}{*}{ (J) Group } & \multirow{2}{*}{$\begin{array}{c}\text { Mean } \\
\text { Difference (I-J) }\end{array}$} & \multirow{2}{*}{$\begin{array}{l}\text { Std. } \\
\text { Error }\end{array}$} & \multirow{2}{*}{ Sig. } & \multicolumn{2}{|c|}{ 95\% Confidence Interval } \\
\hline & & & & & & Lower Bound & Upper Bound \\
\hline \multirow{2}{*}{$\mathrm{pH}$} & MSW II - FMC Treated & Control & 0.000 & 0.160 & 1.000 & -0.419 & 0.419 \\
\hline & MSW III-FMC+BFM Treated & Control & $-0.813^{*}$ & 0.160 & .001 & -1.231 & -0.394 \\
\hline \multirow{2}{*}{$\begin{array}{c}\mathrm{EC} \\
(\mathrm{mS} / \mathrm{cm})\end{array}$} & MSW II - FMC Treated & Control & $-0.370^{*}$ & 0.117 & .021 & -0.676 & -0.064 \\
\hline & MSW III-FMC+BFM Treated & Control & 0.030 & 0.117 & .953 & -0.276 & 0.336 \\
\hline \multirow{2}{*}{$\mathrm{OC}(\%)$} & MSW II - FMC Treated & Control & $9.410^{*}$ & 1.185 & .000 & 6.313 & 12.507 \\
\hline & MSW III-FMC+BFM Treated & Control & $13.093 *$ & 1.185 & .000 & 9.995 & 16.190 \\
\hline \multirow{2}{*}{ Total N (\%) } & MSW II - FMC Treated & Control & $0.705^{*}$ & 0.043 & .000 & 0.592 & 0.818 \\
\hline & MSW III-FMC+BFM Treated & Control & $0.833^{*}$ & 0.043 & .000 & 0.720 & 0.945 \\
\hline \multirow{2}{*}{ Total P (\%) } & MSW II - FMC Treated & Control & $0.088^{*}$ & 0.019 & .003 & 0.037 & 0.138 \\
\hline & MSW III-FMC+BFM Treated & Control & $0.118 *$ & 0.019 & .000 & 0.067 & 0.168 \\
\hline \multirow{2}{*}{ Total K (\%) } & MSW II - FMC Treated & Control & $0.565^{*}$ & 0.034 & .000 & 0.476 & 0.654 \\
\hline & MSW III-FMC+BFM Treated & Control & $0.850^{*}$ & 0.034 & .000 & 0.761 & 0.939 \\
\hline \multirow{2}{*}{ Available N (\%) } & MSW II - FMC Treated & Control & $0.106^{*}$ & 0.010 & .000 & 0.079 & 0.132 \\
\hline & MSW III-FMC+BFM Treated & Control & $0.118^{*}$ & 0.010 & .000 & 0.092 & 0.144 \\
\hline \multirow{2}{*}{ Available P (\%) } & MSW II - FMC Treated & Control & $0.017^{*}$ & 0.004 & .008 & 0.005 & 0.028 \\
\hline & MSW III-FMC+BFM Treated & Control & $0.019^{*}$ & 0.004 & .003 & 0.008 & 0.031 \\
\hline \multirow{2}{*}{ Available K (\%) } & MSW II - FMC Treated & Control & $0.160^{*}$ & 0.012 & .000 & 0.129 & 0.190 \\
\hline & MSW III-FMC+BFM Treated & Control & $0.447 *$ & 0.012 & .000 & 0.417 & 0.478 \\
\hline \multirow{2}{*}{ C:N Ratio } & MSW II - FMC Treated & Control & -0.470 & 0.527 & .594 & -1.848 & 0.908 \\
\hline & MSW III-FMC+BFM Treated & Control & -0.010 & 0.527 & 1.000 & -1.388 & 1.368 \\
\hline
\end{tabular}

*The mean difference is significant at the 0.05 level.

a Dunnett t-tests treat one group as a control, and compare all other groups against it.

\section{Discussion}

The present study was envisaged to treat the MSW by using eco-friendly cost effective method with the help of FMC and FMC+BFM. An effort was made to MSW converting to effective and natural manure through FMC and FMC+BFM. The results emanated from these studies are discussed in this chapter. From the investigation the MSW - III, means which was treated with FMC+BFM was so good compare with MSW - I control and MSW II treated with FMC alone.

MSW that contain, or become contaminated with, untreated human excretions and household wastes like food waste, pet fecal matter, absorbent products, and biosolids are potential sources of pathogenic bacteria [14]. Pathogenic microorganisms may originate from the above sources in MSW and it contain enteric bacterial pathogens may have been found in the study yard. Pahren reported that the lactic acid bacterium having the ability to controls the pathogenic population in MSW [15]. However, Dittoe et al. [16] reported that the colonization of lactic acid bacteria controls the population of pathogenic microorganisms. FMC microbial consortium combinations in the present investigation are in accordance with the observations of Masuda et al. who reported that, increasing the concentrations of lactic acids, it prevents the productions of pathogenic microorganisms on waste product[17]. FMC have two strains of lactic acid bacteria (Lactobacillus fermentum and Lactobacillus bifermentans) which the investigation believes could control the pathogenic microbes. This was encouraging and it is suggested MSW can be used as manure after ruling out the existence of pathogenic microbes, Since MSW have been blamed for the transmission of Salmonella spp and other pathogens to human.

The aromatic substance degradation ability of the Rhodopseudomonas $s p$., in FMC is helpful for the biodegradation process which degrades the pesticide residue in the compost of MSW and indirectly supports the other aromatic sensitive microbial activity [18]. The well-known cellulolytic efficiency of the Cellulomonas fimi will degrade the cellulose material which is present in MSW. Pseudomonas fluorescens are one of the key commercial microbes which are used for plant growth promoter, degrade the pollutants and its oxidizing tolerant efficiency which is help to tolerate all stress conditions. 
Paulsen et al., [19] reported Pseudomonas fluorescens also will suppress the pathogen activity is one of the important factors for waste management system.

Filamentous fungi present in FMC can produce wide range of fine bio-chemicals and enzymes and are more effective than bacteria in metabolizing complex carbohydrates [20]. Saccharomyces cerevisiae is one of the species which is actively involved in fermentation process. During the fermentation process in the MSW management in the study area, it will emit the gases like carbon di oxide and methane. Fortunately, both gases are odorless gases which create an ideal condition for the workers those who are involving the waste management process.

FMC containing Beauveria bassiana is an entomopathogenic fungus that causes white muscadine disease in a range of insects particularly of adult mosquitoes[21] found in MSW and it spores come in contact with a host insect and is infected, the fungus rapidly grows inside of the insect, feeding on the nutrients present in the host's body and producing toxins in the process. When the host dies, the Beauveria bassiana covers the carcass in a layer of white mold that produces more infective spores.

Phanerochate chrysosporium is the most thoroughly investigated white rot fungus in the treatment of hazardous chemicals and wastes and it could degrade broad range of organic and chlorinated organic compounds present in MSW. Phanerochaete chrysosporium having the ability to synthesis of high protein could be influenced by extracellular production of lignocellulosic enzymes leading to the conversion of complex sugar to simple forms that are easily consumed by yeast cells in MSW [22]. Mucor sp. have been found to exhibit high biodegrading activity in MSW due to the secretion of enzymes of amylase and cellulase that was responsible for the biodegradation process $[23,24]$.

Azospirillum orizae in BFM solution having the ability to synthesis of phytohormones and other compounds including Auxins, Cytokinins, Gibberellins, Abscisic Acid, Ethylene and Salicylic Acid which greatly affects the root growth of plants, resulting of improvements in uptake of moisture and nutrients [25]. Azospirillum strains can solubilize inorganic phosphorus present in MSW, making it more readily available form for crops [26].

Rhizobium leguminosarum species present in BFM solution which increases the production of plant growth substances, solubilization of inorganic phosphates, ammonia and antimicrobial compounds on MSW [27]. In addition to plant growth promotion, they can produce enzymes, polysaccharides and antibiotics [28].

BFM solution also containing Frateuria aurantia is a species of Proteobacteria, which is having its character of potash mobilizing and also converting it into utilizable form to the plant roots possesses growth promoting activities through production and secretion of organic acids in MSW[29].The FMC and BFM has influenced in decomposition time and physico-chemical parameters considerably.

$\mathrm{pH}$ value of the was almost neutral in MSW - III treated with FMC+BFM and it could possibly due to the compost stabilized at maturity phase which may be due to the buffering nature of humic substances [30]. The Electrical conductivity value increased during the course of composting. Guoxue et al. and Garg et al. were observed gradual increase in EC in all the substrates under decomposition [31,32]. They attributed to freely available ions and minerals that were generated during microbial decomposition of MSW. Hence, it is suggested that the increase in EC may be due to the degradation of organic matter to release cations, so that the soluble status of MSW - III treated with FMC+BFM was on the higher side.

The percentage of organic carbon in all the composts increases significantly during composting. These results are in accordance with the observations of Inbar et al. who reported that organic carbon content of MSW during composting got high proportion in well matured composts [33]. During the composting process concentration of carbon content in all MSW was increased.

In this study microorganisms also play a vital role in improving the nutrient contents of nitrogen, phosphorus and potassium considerably in MSW - II and MSW III. Bernal et al. who indicated that the nitrogen usually increases during the composting process when volatile solid loss is greater than the loss of ammonia [34]. Metting suggested that the enhancement of potassium with time was due to mineralization of native carbon accompanied by a reduction in the total volume of the waste [35].

The increase in available phosphorus could be due to the fact that the organic acids, carbonic acid and chelating substances, produced during the course of decomposition might have helped in the liberation of Phosphorus [36]. In the maturity phase of MSW - III contains high amount of Nitrogen $(0.27 \pm 0.02 \%)$, Phosphorus $(0.03 \pm 0.01 \%)$ and Potassium $(0.56 \pm 0.03 \%)$ compare with control $(\mathrm{N}$ : $0.15 \pm 0.00 \%, \mathrm{P}: 0.01 \pm 0.00 \%, \mathrm{~K}: 0.11 \pm 0.01 \%)$ as well MSW - II (N: $0.25 \pm 0.01 \%$, P: $0.03 \pm 0.01 \%, \mathrm{~K}: 0.27 \pm 0.01$ ). The result clearly indicates that the quality of the MSW III was so good when compared with MSW - I control and MSW - II treated with FMC.

Apart from the quality of three composts, the MSW - III nature and decomposition rate are high. The volume reductions were more when compare with MSW - I Control and MSW - II FMC+BFM application on MSW in the present study offers high hope in converting this into effective manure for farming. In comparison with MSW - I control and MSW - II the FMC treated with MSW - III FMC+BFM treated has less organic carbon, more nitrogen and phosphorous. Any type of organic matter could be composted with FMC+BFM technology, as there is no development of offensive odor, more than $80 \%$ reduction were observed within 25 days with this microbial solution. 


\section{Graphical Analysis}

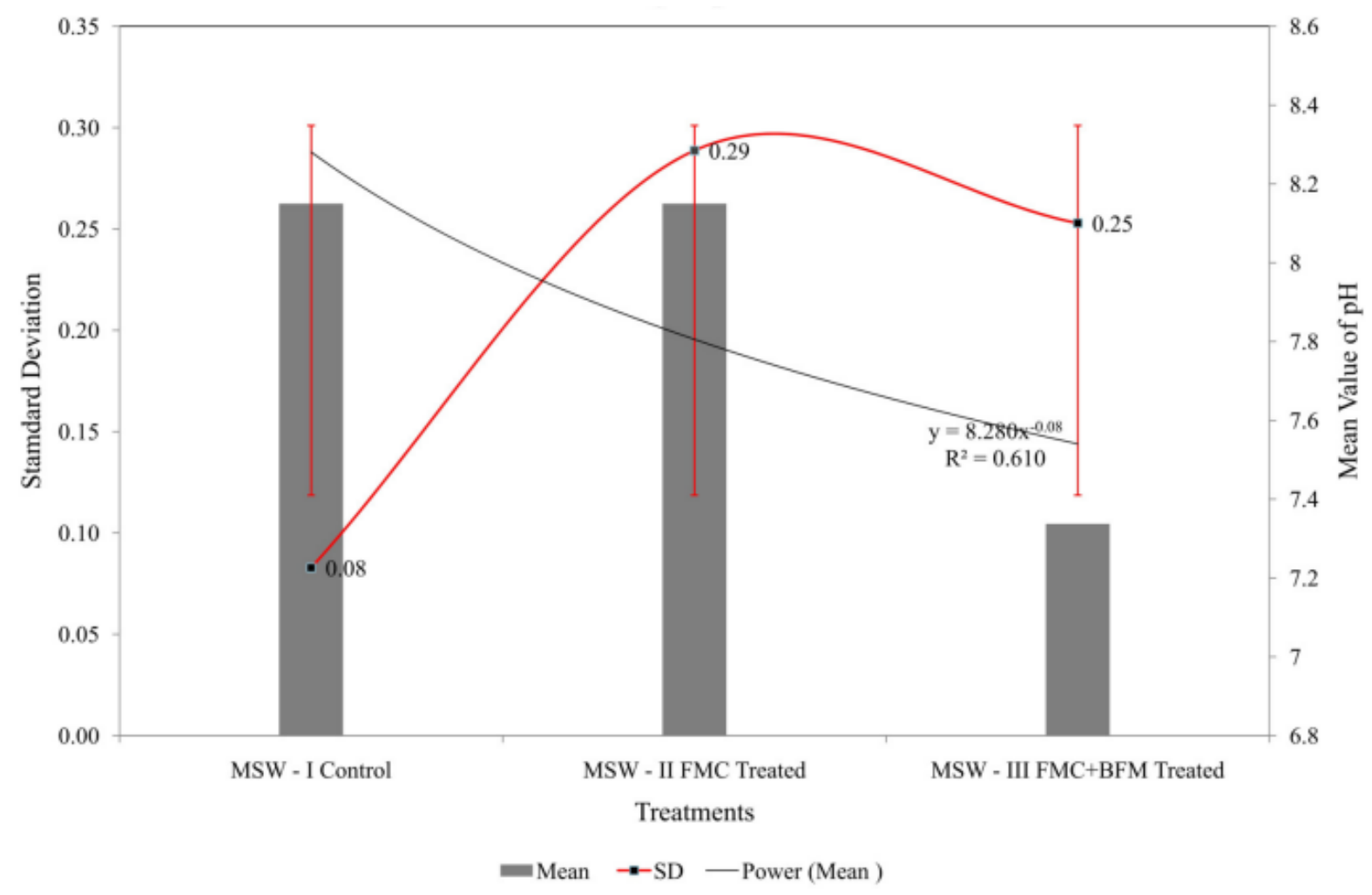

Figure 2. $\mathrm{pH}$

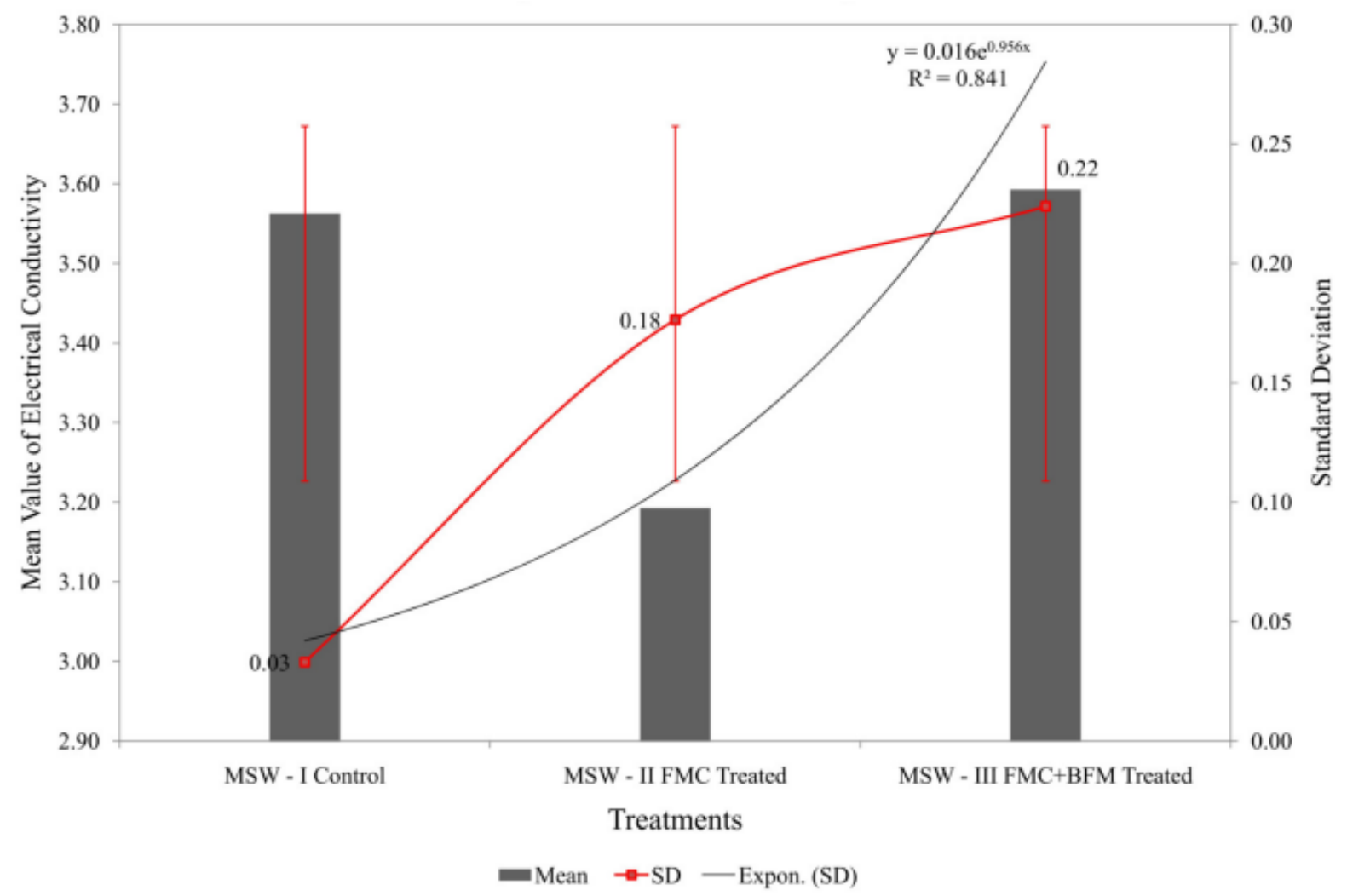

Figure 3. Electrical Conductivity 

Formulated Microbial Consortium Along with Bio Fertilizer Microorganisms

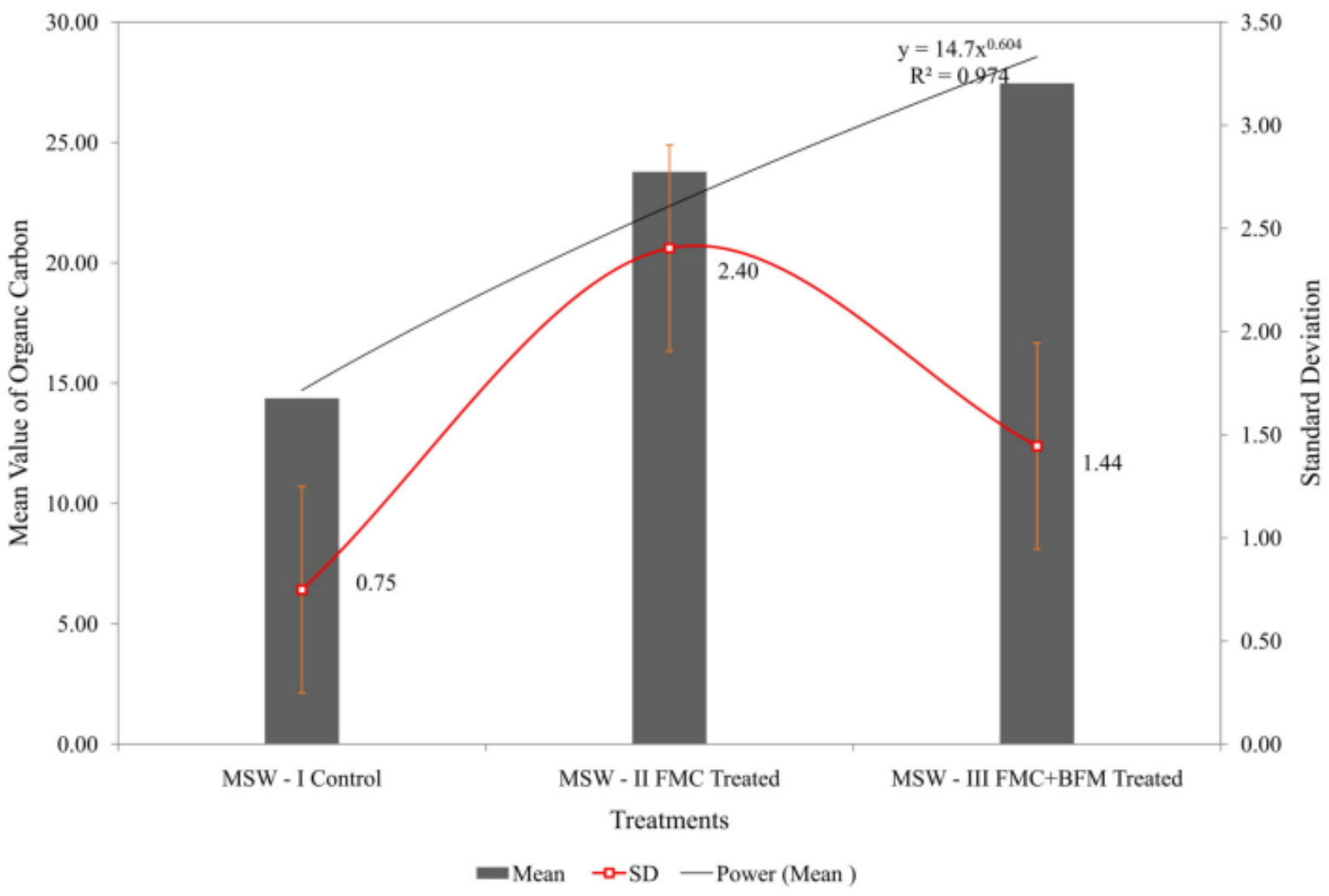

Figure 4. Organic Carbon

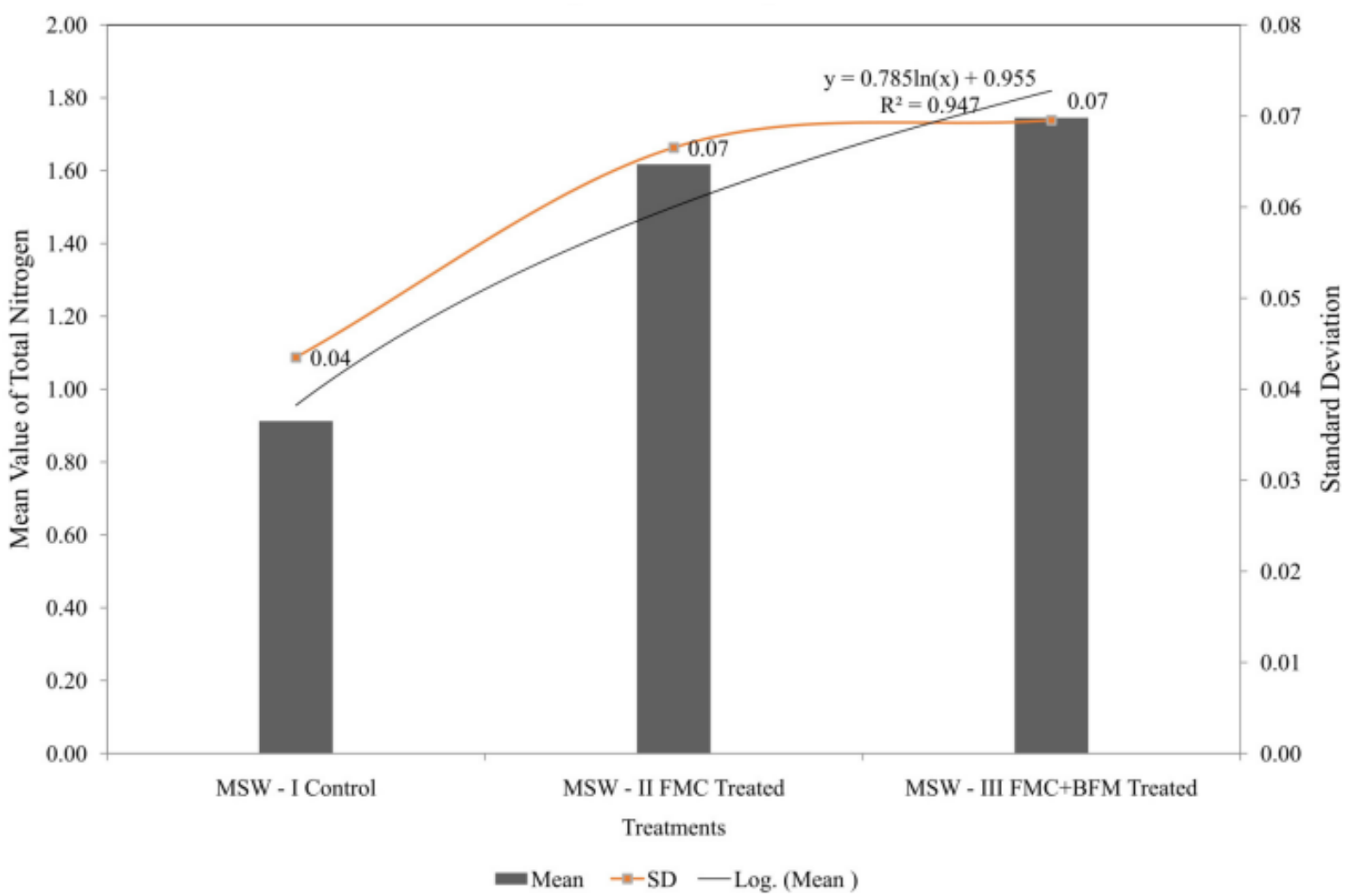

Figure 5. Total Nitrogen 


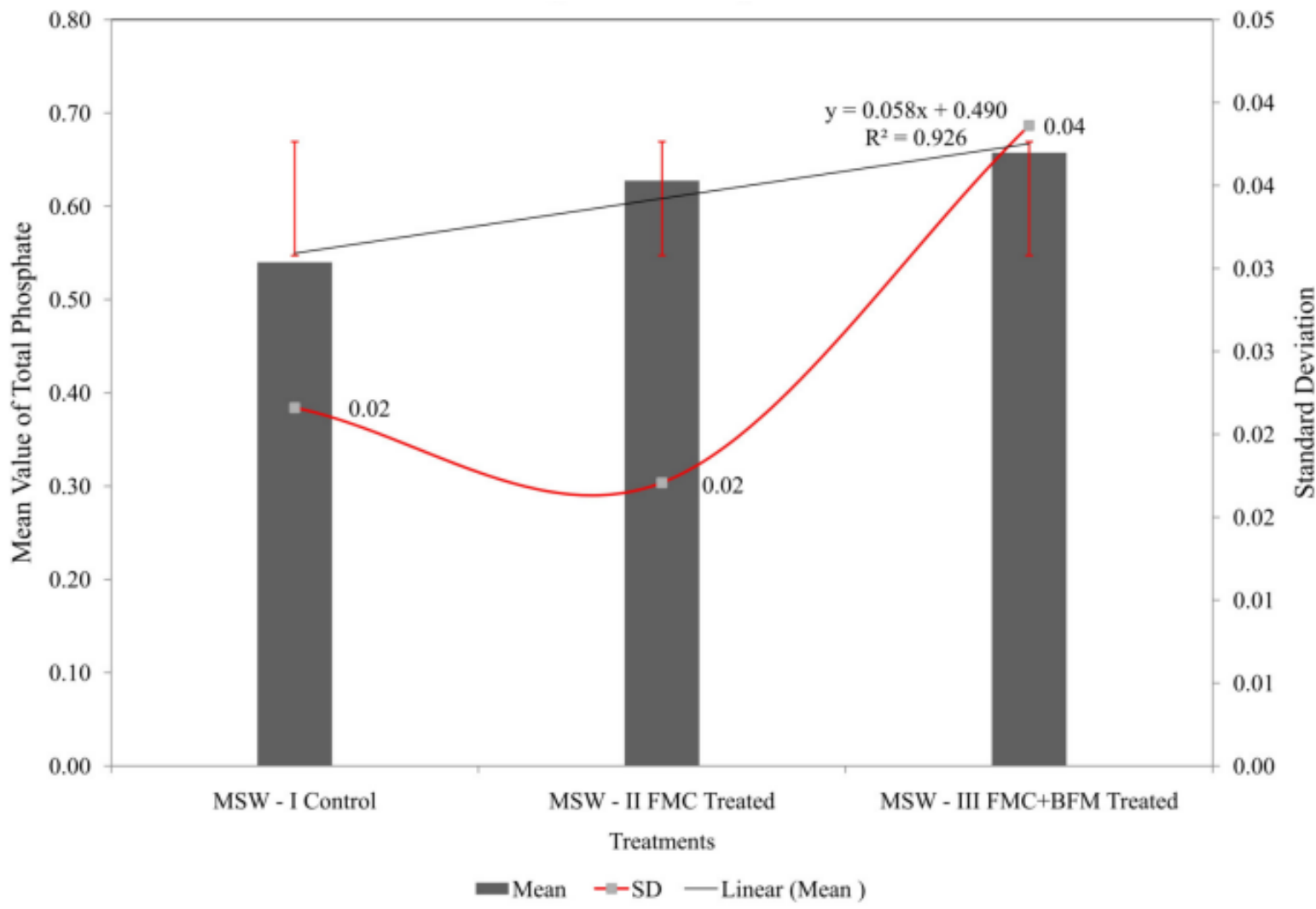

Figure 6. Total Phosphorus

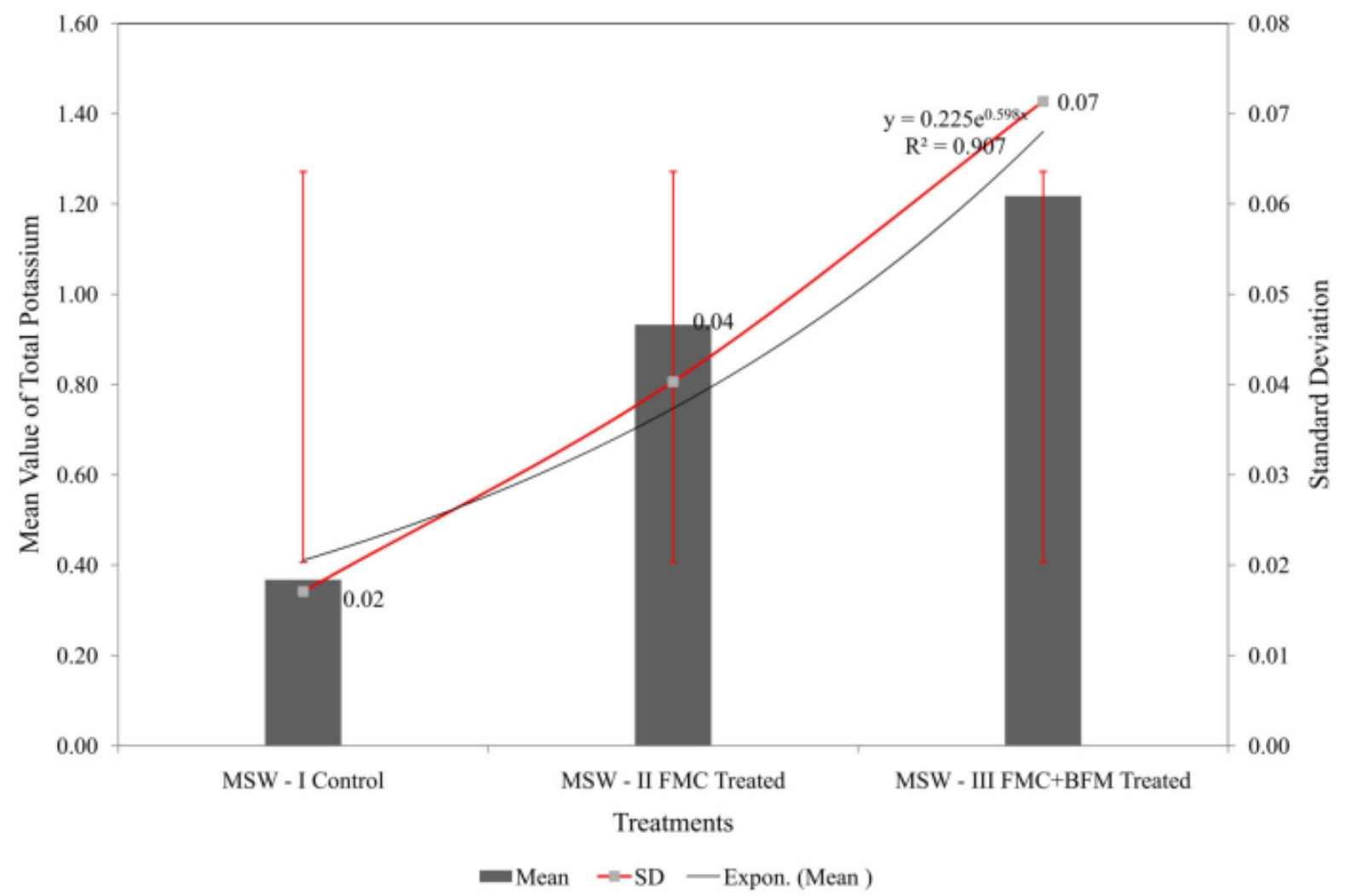

Figure 7. Total Potassium 


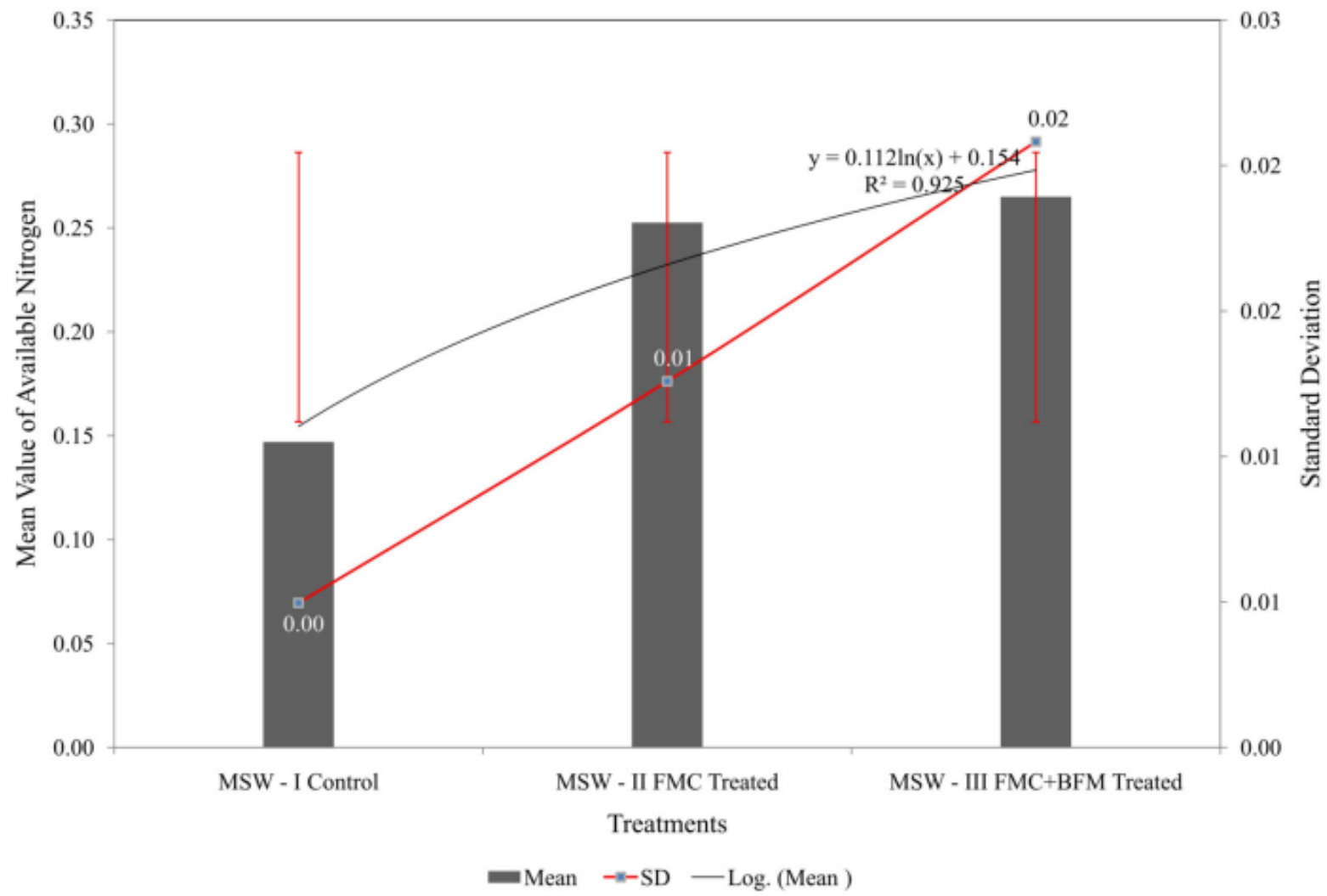

Figure 8. Available Nitrogen

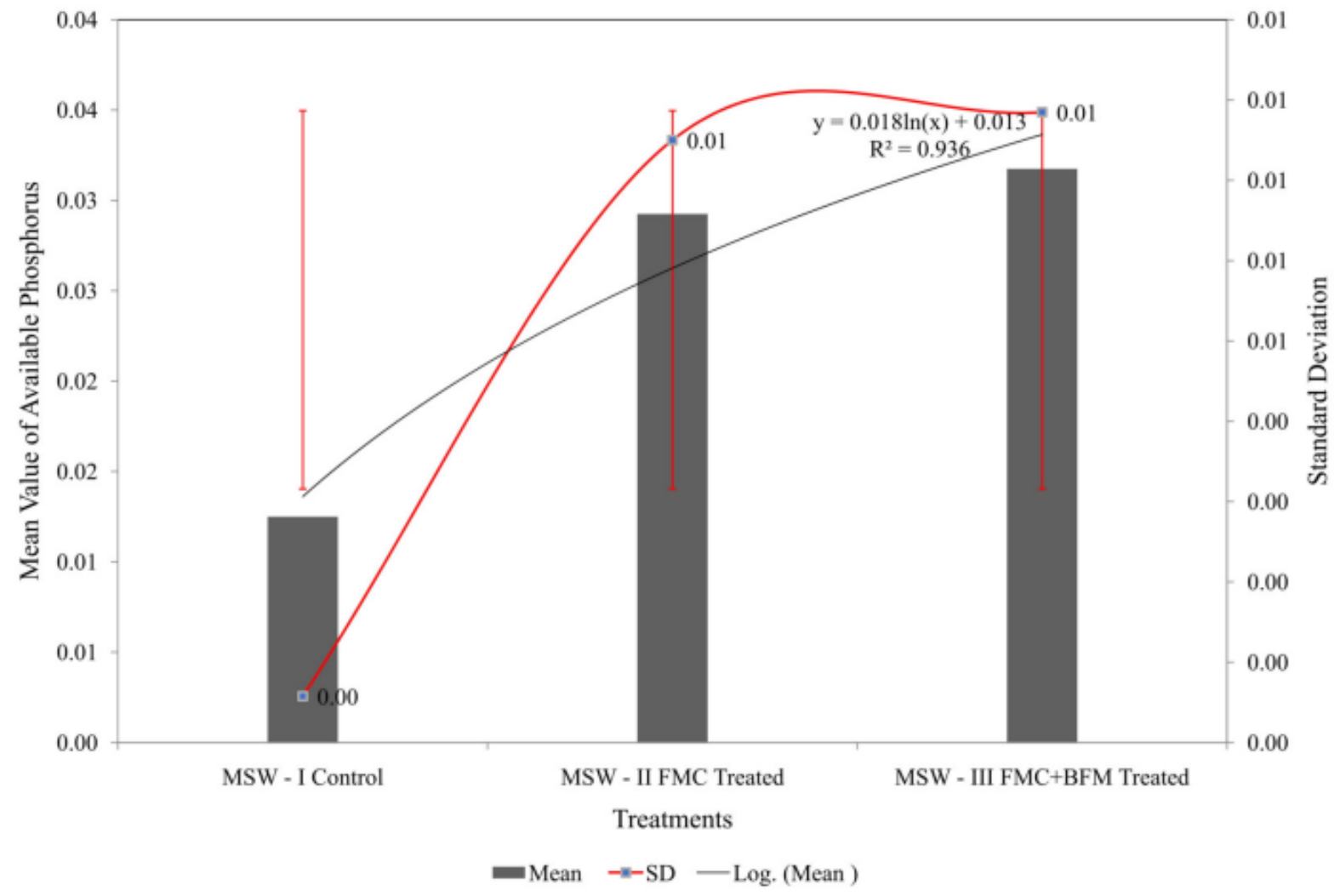

Figure 9. Available Phosphorus 


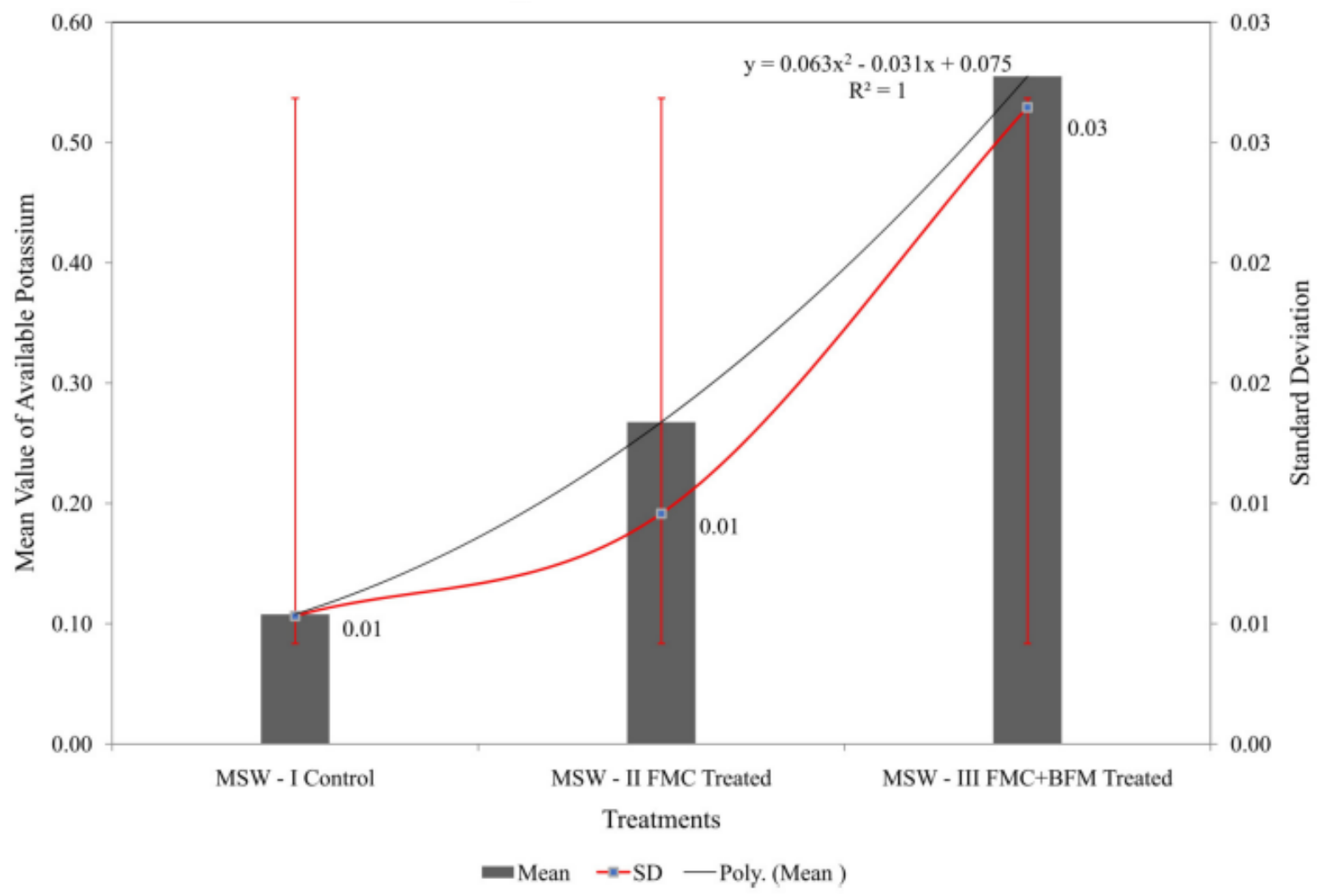

Figure 10. Available Potassium

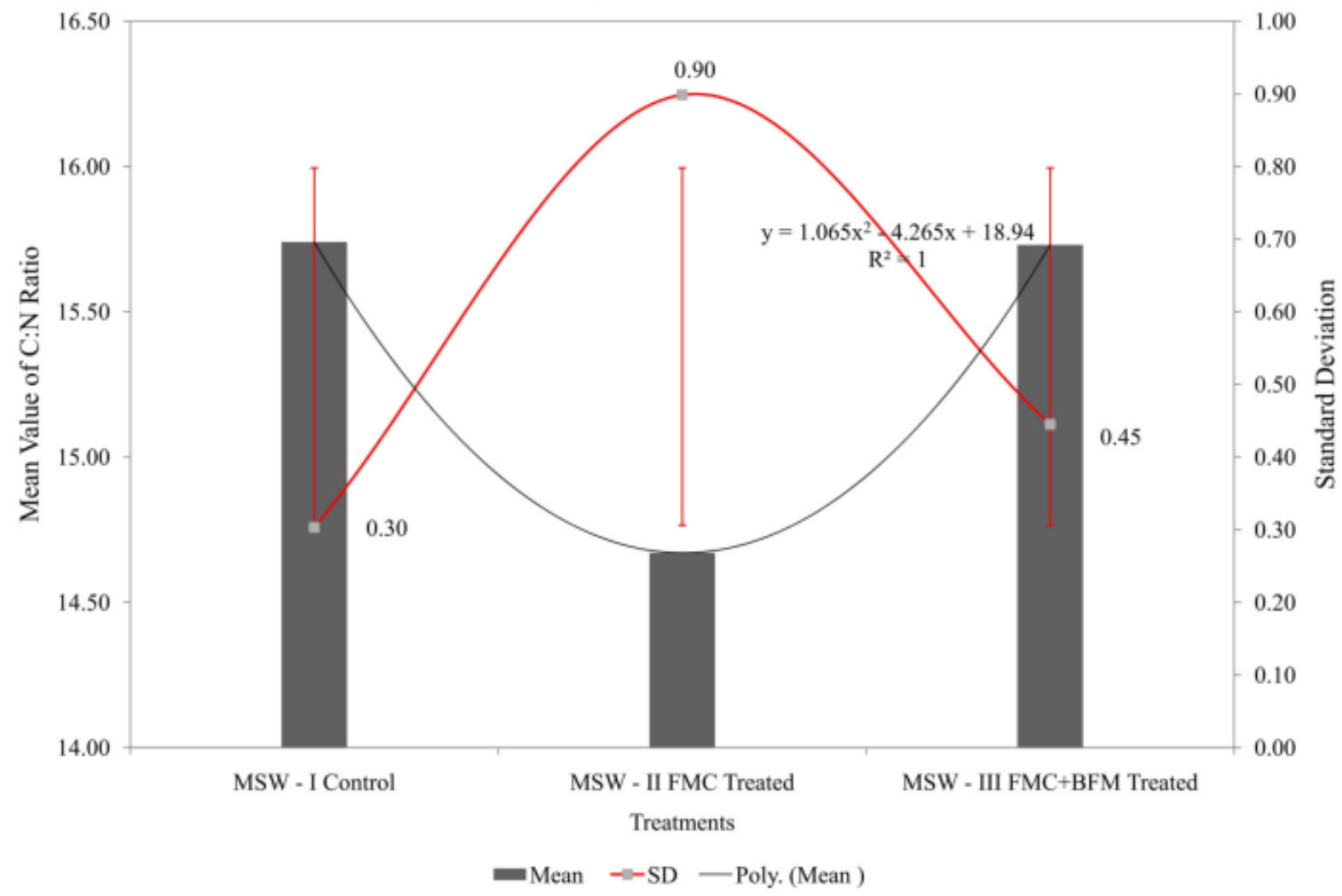

Figure 11. CN Ratio 


\section{Conclusions}

In the present study majorly focus on treatment and utilization of MSW as manure for agriculture. The evaluation of yard compost by nutrient analysis revealed that the addition of some composting microbial consortium along with biofertilizer microorganism gave good quality compost as compared with the treatment having natural composting process. After the experiment it shows that the FMS along with BFM was working effectively.

\section{Acknowledgements}

The authors thank the Tamil Nadu State Council for Science and Technology, Chennai, Tamil Nadu, India for providing financial assistance through the project "TNSCST/DST-PRG/TD-AWE/VR/05/2017" for carrying out the research work successfully.

\section{REFERENCES}

[1] Ministry of Rural Development. Solid and liquid waste management in rural areas: A technical note. Department of drinking water supply, New Delhi, India, 110pp.2007.

[2] AM. Bruce. Sewage sludge processing: progress and problems. In: L'Hermite, P., (Eds) Sewage treatment and use of sewage sludge and liquid agricultural wastes. Elsevier. Appl. Sci.1990

[3] R. Joshi. S. Ahmed. Status and challenges of municipal solid waste management in India: A review. Cogent Environ. Sci, Vol. 2: 1139434. 2016.

[4] HA. Elliott. Land Application of Municipal Sewage Sludge. J. Soil. Wat. Consr. Vol.41: 5-10.1986

[5] S. Sahu, SJ. Nair, PK. Sharma. Review on Solid Waste Management Practice in India: A State of Art. Int. J.Inn. Res. Dev. Vol.3, No.3, 261-264.2014.

[6] S. Rathi. Alternative approaches for better municipal solid waste management in Mumbai, India. J. Waste Mgt. Vol.26, No.10, 1192-1200, 2006.

[7] DJ. Mishra, S. Rajvir, UK. Mishra, SS. Kumar. Role of Bio-Fertilizer in Organic Agriculture: A Review. Res. J. Rec. Sci. Vol. 2. 39-41, 2013.

[8] PK. Pindi. SDV. Satyanarayana. Liquid Microbial Consortium- A Potential Tool for Sustainable Soil Health. J Biofertil Biopestici 3:124, (2012).

[9] American Public Health Association. Standard Methods for the Examination of Water and Wastewater. (20 th $\mathrm{ed}$.), American Public Health Association, Washington DC.1998.

[10] CA. Black. Methods of Soil Analysis, Vol. 2. American Society of Agronomy, USA.1965.

[11] AI. Vogel. A textbook of quantitative inorganic analysis. Longman, Green.1961.
[12] G. Wen, TE. Bates, RP. Voroney, JP. Winter, MP Schellenbert. Comparison of Phosphorus availability with application of sewage sludge, sludge compost, and manure compost. Commu. Soil Sci. Plant Anal. Vol.28, 1481-1497, 1997.

[13] ML. Jackson. Soil chemical analysis. Prenice-Hall, London. 1968.

[14] CP. Gerba, AH. Tamimi, C. Pettigrew, AV. Weisbrod V. Rajagopalan. "Sources of microbial pathogens in municipal solid waste landfills in the United States of America" Waste Mgt. \& Res. Vol.29, No.8, 781-790, 2010.

[15] HR. Pahren. CS. Clark. Microorganisms in municipal solid waste and public health implications. Critical Rev. Environ. Contl. Vol. 17, 187-228.1987.

[16] DK. Dittoe, SC. Ricke, AS. Kiess. Organic acids and potential for modifying the avian gastrointestinal tract and reducing pathogens and disease. Front. Vet. Sci. Vol.5, No. 216, 1-12.2018.

[17] S. Masuda, Y. Hara-Kudo, S. Kumagai. Reduction of Escherichia coli O157; H7 populations in soy sauce, a fermented seasoning. J. Food Protec. Vol.61, 657-661.1998.

[18] PG. Egland, J. Gibson, CS. Harwood. Reductive coenzyme A-Mediated pathway for 3-Chlorobenzoate degradation in the phototrophic bacterium Rhodopseudomonas palustris". Appl. Environ. Microbiol. Vol.67, No.3, 1396-1399.2001.

[19] IT. Paulsen, CM. Press, J. Ravel. Complete genome sequence of the plant commensal Pseudomonas fluorescens Pf-5. Nat. Biotechnol. Vol.23, 873-878.2005.

[20] J. Van Leeuwen, Z. Hu, TW. Yi, A.L. Pometto, B. Jin Kinetic model for selective cultivation of microfungi in a microscreen process for food processing wastewater treatment and biomass production. Acta Biotechnol., Vol.23, 289-300.2003.

[21] J. Snetselaar, R. Andriessen, RA. Suer, AJ. Osinga, BGJ. Knols, M. Farenhorst. Development and evaluation of a novel contamination device that targets multiple life-stages of Aedes aegypti. Parasit \& Vect. Vol.7, 200.2014.

[22] L. Ke, Q. Wu, D. Zhang. Bioconversion of rape straw into a nutritionally enriched substrate by Ganoderma lucidum and yeast. African J. Biotechnol. Vol.10, 5648-5653.2011.

[23] SN. Chinedu, AO. Eni, AI. Adeniyi JA. Ayangbemi, Assessment of growth and cellulase production of wild type microfungi isolated from Ota, Nigeria. Asian J. Plant Sci. Vol.9, No.3, 118-125.2010.

[24] V. Poonam, D. Ankur, C. Varsha, A. Jamaluddin. Studies on enzymatic potential fungi isolated from municipal solid waste in Jabalpur. Int. J. Rec. Sci. Res. Vol.6, No.8, 5927-5932.2015.

[25] M. Ardakani S. Mafakheri. Designing a sustainable agroecosystem for wheat (Triticum aestivum L.) production. J. Appl. Environ. Biol. Sci. Vol.1, 401-413, 2011.

[26] M. Turan, M. Gulluce, W.N. Von, F. Sahin. Yield promotion and phosphorus solubilization by plant growth-promoting rhizobacteria in extensive wheat production in Turkey. J. Plant. Nutr. Soil Sci. Vol. 175, 818-826, 2012.

[27] RC. Dubey, DK. Maheshwari, H. Kumar, K. Choure. 
Assessment of diversity and plant growth promoting attributes of rhizobia isolated from Cajanuscajan L. African. J. Biotechnol. Vol. 9, 8619-8629, 2010.

[28] VK. Deshwal, P. Pandey, SC. Kang, DK. Maheshwari. Rhizobia as a biological control agent against soil borne plant pathogenic fungi. Indian. J. Exp. Biol. Vol. 41, 11601164, 2003.

[29] HS. Han, KD. Lee. Phosphate and potassium solubilizing bacteria effect on mineral uptake, soil availability and growth of eggplant. Res. J. Agri. Biol. Sci. Vol. 1 176-180, 2005.

[30] PS. Arunadevi. Sustainable waste management strategy for dairy industry. Ph.D., Thesis. Bharathiar University, Coimbatore, TN. India. 2010.

[31] LI. Guoxue, F. Zhang, Y. Sun, JWC. Wong, M. Fang. Chemical evaluation of sewage composting as mature indicator for composting process. Water Air Soil Sludge Pollut. Vol.132, 333 - 345, 2001.
[32] NK. Garg, P. Kaushik, N. Dilbaghi. Vermiconversion of wastewater sludge from textile mill spiked with anaerobically digested biogas plant slurry employing Eisenia foetida. Ecotoxicol. Environ. Safety. Vol. 65, 412-419, 2006.

[33] Y. Inbar, Y. Chen, Y. Hadar. Humic substances formed during the composting of organic matter. Soil Sci. Society of America J. Vol.54, 1316-1323,1990.

[34] MPC. Bernal, M. Paredes, A. Sanchez, J. Cegarra. Maturity and stability parameters of composts prepared with a wide range of organic wastes. Biores. Technol. Vol.63, 91-99, 1998.

[35] FB. Metting. Soil microbial ecology-Application of agricultural and environmental management. Marcel Dekkar, New York. 1993.

[36] SH. Chien. Dissolution of phosphate rock in acid soils as influenced by nitrogen and potassium fertilizers. Soil Sci. 127: 371-376, 1979. 